\title{
Built-up Edge Formation in Machining AlSi7Mg0.3 Alloy
}

Michal Martinovsky, Jan Madl, Jan Vitner

Faculty of Production Technology and Management, J. E. Purkyne Univerzity in Usti nad Labem, Pasteurova 3334/7, 400 01, Usti nad Labem, Czech Republic., E-mail: martinovsky@fvtm.ujep.cz, madl@fvtm.ujep.cz

One of the main problems in machining $\mathrm{Al}$ alloys represents built-up edge formation. This paper is focused on the effect of selected modifiers in AlSi7Mg0.3 alloy on built-up edge formation. Four variants of castings modified by strontium, calcium and antimony are used. All these alloys are compared with non-modified alloy. Built-up formation leads to the increasing of surface roughness for both types of built-up edge - unstable or stable. If unstable built-up edge is produced, surface roughness increases enormously. Therefore the research is focused on surface roughness in different cutting conditions. There were moulded castings of non-modified alloy and for each modified variant. Gravity-die castings into a metal mould with a thermal insulation were made.

Keywords: AlSi7Mg0.3 alloy, Modifiers, Machining, Built-up edge

\section{Acknowledgements}

The article was co-financed through internal grant provided from J. E. Purkyne University in Usti nad Labem, called SGC, i.e. the Student Grant Competition.

\section{References}

[1] MADL, J., KOUTNY, V. (2000). Machinability Tests of Aluminium Alloys. In: MATAR, FS ČVUT, Praha, pp. 124-127.

[2] PALMAI, Z. (2013). Model of Chip Formation During Turning in the Presence of a Built-up Edge. Manufacturing Technology, Vol. 12, No. 13, Univerzita J. E. Purkyne, Usti nad Labem, pp. 207-212. ISSN 1213-2489.

[3] VASILKO, K. (2006). Physical and Metallurgical Approach to Chip Creation. Manufacturing Technology, Vol. 6, No. 6, Univerzita J. E. Purkyně, Usti nad Labem, pp. 56-62. ISSN 1213-2489.

[4] MADL, J., KOUTNY, V. (1998). Surface Quality and Cutting Fluids. Nauka, inovacionnye proizvodstva, menedzment (Russia). No. 7-8, pp. 166-169.

[5] KOCMAN, K. (2004). Specialni technologie obrabeni. FSI VUT, Brno, pp 155, ISBN 80-214-2562-8

[6] BOOTHROPYD, G. (1975). Fundamentals of Machining and Machine Tools, MARCEL DEKKER, New York, pp. 545, ISBN 0-8247-7852-9.

[7] MARTINOVSKY, M., MADL, J. (2016). The Effect of Different Modifiers in AlSi7Mg0,3 Alloy on Built-up edge Formation in Machining. Manufacturing Technology, Vol. 16, No. 1, pp. 173-178. ISSN 1213-2489.

[8] KROLCZYK, G., NIESLONY, P. LEGUTKO, S. (2015). Determination of Tool Life and Research Wear During Duplex Stainless Steel Turning. Archives of Civil and Mechanical Engineering, Vol. 15, No. 2, pp. 347-354.

[9] KROLCZYK, G., GAJEK, M., LEGUTKO, S. (2013). Predicting the Tool Life in the Dry Machining of Duplex Stainless Steel. Expluatacia i Niezavodosc - Maintenance and Reliability, Vol. 15, No. 1. pp. 62-65.

[10] BOLIBRUCHOVA, D., TILlOVA, E. (2005). Zlievarenske zliatiny Al-Si, ZU, Zilina, pp. 180. ISBN 80-87-485-6.

[11] MARTINOVSKY, M., MADL, J. (2014). Vliv modifikatoru na obrobitelnost a vlastnosti Al-Si slitin. Strojírenská technologie, Vol. 14, No. 3, FVTM UJEP, Usti ad Labem, pp. 212-219. ISSN 1211-4162.

[12] MADL, J., RUZICKA, L., LATTNER, M. (2013). The Effect of Chemical Elements on the Machinability of Aluminium Alloys. Manufacturing Technology, Vol. 13, No. 3, pp. 349-353. ISSN 1213-2489.

[13] STEFAN MICHNA et al. (2007). Aluminium Materials and Technologies from A to Z. Adin, Presov, p. 632. ISBN 9789-80-89244-18-8.

[14] ALUMINIUM TASCHENBUCH (1988). Aluminium-Verlag, Dusseldorf, pp. 234. 